\title{
Characteristics of medication use during lactation
}

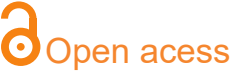

${ }^{1}$ Marília School of Medicine Marília (SP), Brazil

\section{Corresponding author: lazarini@famema.br}

Manuscript received: January 2018 Manuscript accepted: April 2018 Version of record online: June 2018

\author{
Taís Albano Hernandes ${ }^{1}$, Alessandra Nikaido Fuginami ${ }^{1}$, \\ Enrique Caetano Raimundo', Cristina Peres Cardoso ${ }^{1}$, Elza de \\ Fátima Ribeiro Higa ${ }^{1}$, Carlos Alberto Lazarini ${ }^{1}$
}

\begin{abstract}
Introduction: The importance of breastfeeding is undisputed. It provides benefits to infants, nursing mothers, families, and society as a whole. The World Health Organization encourages a diet of exclusive breastfeeding until six months of age; however, this routine may be unfeasible for many reasons, one of which is the mother's use of medication.
\end{abstract}

Objective: To characterize medications used by nursing mothers in terms of risk categories, place of care and medical professionals responsible for the prescription, and the extent of medical advice received by the mothers.

Methods: This is a retrospective, quantitative, and cross-sectional study. The data were collected from Brazil's Family Health Strategies (ESF) program and included information on 161 nursing mothers from 2012 and 2013 and their use of medications while breastfeeding. The data were considered in absolute and relative frequencies and compared to the secondary variables in the study in order to determine whether any associations existed. The chisquare test was applied as part of the analysis.

Results: Of the nursing mothers interviewed, $55.9 \%$ reported taking medication. The most frequent groups of medications were those affecting the genito-urinary system and sex hormones, endocrine system, followed by systemic and cardiovascular medications. In the ESF program, general practitioners were the medical professionals who most frequently prescribed medication to these women, followed by gynecologists. Of the women who received prescriptions, $64.4 \%$ received some type of medical advice. The statistical analysis revealed a positive correlation between risk category and medical specialty $(p=0.03)$, as well as between risk category and place of care $(p=0.001)$.

Conclusion: The most frequently used drug class was that of contraceptives. All medication classified as contraindicated was found to have been prescribed as part of primary care by general practitioners. Thus, these results reflect the need for more qualified professionals throughout Brazil's public health care network.

Keywords: breastfeeding, prescription medications, lactation, maternal-infant health, primary health care.

Suggested citation: Hernandes TA, Fuginami AN, Raimundo EC, Cardoso CP, Higa EFR, Lazarini CA. Characteristics of medication use during lactation. J Hum Growth Dev. 2018; 28(2):113-119. DOI: http://dx.doi.org/10.7322/jhgd.147215 


\section{INTRODUCTION}

Breastfeeding is an age-old practice among humans and is influenced by multiple issues, including biological, psychological, spiritual, family-related, environmental, social, and economic factors ${ }^{1}$.

Breast milk is a complete food that contains vitamins, minerals, fats, sugars, and proteins, and it is recommended for the proper nutrition of newborns. In addition to its nutritional advantages, breast milk promotes the best development of the baby's oral cavity, prevents diarrhea and respiratory infections, and boosts immunological protection, thus decreasing infant mortality ${ }^{2}$. It also protects against overweight and diabetes throughout life ${ }^{3}$.

It addition to supplying the baby's nutritional needs, breastfeeding encourages close interaction between mother and child, with benefits for the baby's physiological, cognitive and emotional development ${ }^{4}$.

Brazilian legislation guarantees women the right to breastfeed their children. The World Health Organization (WHO) and the Brazilian Ministry of Health encourage a diet of exclusive breastfeeding until six months of age and consistent breastfeeding until two years of age, with the gradual introduction of new foods. Brazil's Constitution and public health care laws mandate maternity leave, as well as the right to day care and breastfeeding breaks ${ }^{5}$. Despite these options and recommendations, early termination of breastfeeding is common ${ }^{6}$. Premature weaning may lead to delayed neurological and psychomotor development in the first three years of life ${ }^{7}$.

Many factors may contribute to premature weaning. These include the mother's lack of knowledge on the advantages and importance of breastfeeding ${ }^{8,9}$, insufficiently trained health care professionals, public policies that only weakly promote breastfeeding, women's increasingly active role in the labor market ${ }^{10}$, a lack of interest on the part of the newborn, decreased breast milk production and expression, decreased nutritional capacity of the mother's breast milk, physical problems in the breasts ${ }^{11}$, and the use of medications during lactation ${ }^{12}$.

Because the use of pharmaceuticals during lactation can contribute to early weaning, the Brazilian Ministry of Health provides guidelines on medications that are safe for consumption during breastfeeding, identifying the drugs according to their category of risk. The categories established by the Brazilian Ministry of Health are compatible with breastfeeding, potential for risk if used during breastfeeding, and contraindicated during breastfeeding ${ }^{13}$.

\section{METHODS}

This was a cross-sectional, retrospective, and quantitative study performed in a city located in the centralwestern region of São Paulo State, the population of which is approximately 230,000 inhabitants.

The subjects were mothers who met the inclusion criteria: they were patients enrolled in Brazil's Family Health Strategies (ESF) program who had breastfed in 2012 and 2013. The sample size was calculated using the following statistical parameters: total live births in the southern region of the city (the region which had the highest number of
Brazil's public primary care system consists of two types of practices: family health care centers, known locally as USFs, and basic health care centers, known locally as UBSs. Most nursing mothers visit USFs for their initial treatment and may visit or be transferred to UBSs or secondary or tertiary care centers for more urgent or specialized care. Care at USFs is provided solely by general practitioners. A previous study found that the most commonly used medications in one UBS, were iron and vitamin supplements $(59 \%)$, nonsteroidal antiinflammatory drugs, or NSAIDs (15\%), hormones (2\%), antibiotics (7\%), and antifever medications (2\%), with only $1 \%$ of patients discontinuing breastfeeding because they needed to use lithium carbonate ${ }^{14}$. Other drugs responsible for discontinuation included diazepam, which caused sleepiness in the newborn; doxepin, which induced vomiting and jaundice in the baby, and ethinylestradiol, a hormonal contraceptive that has been found to decrease the production of breast milk ${ }^{15}$.

In another study, also performed at a UBS in Brazil, $80 \%$ of the participants used medication during breastfeeding; NSAIDs were the most commonly used (58\%), followed by contraceptives $(11 \%)$ and antianemic drugs $(11 \%)$. In the study, $58.3 \%$ of the nursing mothers received no medical advice regarding the use of medication while breastfeeding ${ }^{16}$.

According to the Brazilian Ministry of Health, some of these medications are not safe for use while breastfeeding. This risk is compounded by the lack of research on this topic in the country. Thus, medical professionals responsible for prescribing medication to nursing mothers must receive more information in an attempt to improve care for both mothers and babies during this important time. If prescription medication is necessary in this period, the medical professionals must know the factors involved, particularly in terms of the metabolic and physiological aspects of human breast milk, since it is these issues which determine the safety of the drug use during breastfeeding ${ }^{13}$. Therefore, the motivation for this research was the need for knowledge and training on the use of medications during lactation by all professionals in the health care network who care for breastfeeding women and their children.

In light of these factors, this study sought to characterize the medications taken by nursing mothers in terms of risk categories, places and medical professionals responsible for the prescription, and the medical advice received by the mothers.

births; $n=467$ ), a sampling error of $5 \%$, a $95 \%$ confidence level and a maximum percentage of $78 \%$; thus, 161 nursing mothers were required.

Data was collected through at-home interviews using a standardized and semi-structured questionnaire adapted from Fragoso et al. ${ }^{17}$ Data was collected on sociodemographic characteristics (mother's age, level of schooling, and age of the baby) and medications (use, drug class, prescribing physician's medical specialty, place of prescription, and advice received on use during breastfeeding). 
Patients were excluded from the study if they missed more than three medical visits and if they changed the USF in which they were enrolled.

In order to identify the medications, the researcher asked each nursing mother to present all of the medications she was taking. The categories into which the drugs were classified were those provided by the Anatomical Therapeutic Chemical Classification System (ATC) ${ }^{18}$. After their identification, the drugs were classified by risk of use during breastfeeding ${ }^{19}$.

The data were processed and analyzed using the SPSS Software, version 17.0. Sociodemographic variables and variables involving the medications are presented as absolute and relative frequencies. Category

\section{RESULTS}

The sociodemographic data of the 161 participants revealed a predominance of patients between 20 and 29 years of age and a majority of patients who had completed high school as their highest level of schooling.

Most subjects reported having used some type of medication while breastfeeding. Table 1 describes the of risk was treated as an independent variable and was compared to the following dependent variables: the stage of lactation during which the medication was prescribed, the prescribing physician's medical specialty, the place where the prescription was made, and whether the nursing mother received medical advice. The chi-square test was used to determine any associations between the variables. Associations between variables were considered statistically significant when $\mathrm{p} \leq 0.05$.

The study was approved by the Research Ethics Committee of the Marília School of Medicine under case number 133.616 and by the Municipal Research Assessment Board run by the Municipal Health Secretariat (COMAP) under case number 373/12-SS.

142 prescription drugs that were used by the mothers interviewed. The most commonly used drugs were those in the hormonal system ATC group, followed by the antiinfectives for systemic use group and the cardiovascular system group.

Table 1: Groups and subgroups of prescription drugs used by the nursing mothers interviewed in this study. Marília, São Paulo, 2014. The data are presented as absolute frequencies $(n)$ and as percentages.

\begin{tabular}{|c|c|c|}
\hline Parameter & $n=142$ & $\%$ \\
\hline \multicolumn{3}{|l|}{ Medications used? } \\
\hline Yes & 90 & 55.9 \\
\hline No & 71 & 44.1 \\
\hline \multicolumn{3}{|l|}{ ATC Classification Group* } \\
\hline \multicolumn{3}{|l|}{ Cardiovascular System } \\
\hline Antihypertensive drugs & 21 & 14.8 \\
\hline \multicolumn{3}{|l|}{ Alimentary Tract and Metabolism } \\
\hline Digestive System & 4 & 2.8 \\
\hline Drugs used in diabetes & 3 & 2.1 \\
\hline \multicolumn{3}{|c|}{ Systemic Hormonal Preparations, excl. Sex Hormones and Insulins } \\
\hline Thyroid therapy & 2 & 1.4 \\
\hline \multicolumn{3}{|l|}{ Genito-Urinary System and Sex Hormones } \\
\hline Non-combined contraceptive & 38 & 26.8 \\
\hline Combined contraceptive & 11 & 7.7 \\
\hline Unspecified contraceptive & 12 & 8.4 \\
\hline \multicolumn{3}{|l|}{ Blood and Blood-Forming Organs } \\
\hline Antithrombotic agents & 1 & 0.7 \\
\hline Antianemic & 2 & 1.4 \\
\hline \multicolumn{3}{|l|}{ Nervous System } \\
\hline Opioid & 1 & 0.7 \\
\hline Antihistamine & 2 & 1.4 \\
\hline \multicolumn{3}{|l|}{ Musculoskeletal System } \\
\hline Anti-inflammatory and Antirheumatic Products & 11 & 7.7 \\
\hline \multicolumn{3}{|l|}{ Antiparasitic Products, Insecticides and Repellents } \\
\hline Antimalaria & 1 & 0.7 \\
\hline \multicolumn{3}{|l|}{ Anti-infectives For Systemic Use } \\
\hline Antibiotics & 25 & 17.6 \\
\hline \multicolumn{3}{|l|}{ Topical Medications } \\
\hline Antifungal Creams & 1 & 0.7 \\
\hline \multicolumn{3}{|l|}{ Various } \\
\hline Vitamin supplements & 5 & 3.5 \\
\hline Patient unable to provide name of medication & 2 & 1.4 \\
\hline
\end{tabular}

*Anatomical Therapeutic Chemical Classification System (ATC) 
General practitioners were the most common medical specialists to prescribe drugs to these mothers, followed by gynecologists. Most of the prescriptions were provided at USFs, followed by UBSs. Most of the interviewees received some type of medical advice regarding which medications were safe to use while breastfeeding (Table 2).
The statistical analysis showed a positive correlation between risk classification and the variables representing the prescribing physician's specialty and the place of care. The highest percentages of prescriptions of drugs with potential for risk if used during breastfeeding and of drugs contraindicated during breastfeeding were made by general practitioners in the ESF program (Table 3).

Table 2: Information on prescriptions provided to the nursing mothers interviewed. Marília, São Paulo, 2014. The data are presented as absolute frequencies $(n)$ and as percentages.

\begin{tabular}{lcc}
\hline Variable & $\mathbf{n = 9 0}$ & $\mathbf{\%}$ \\
\hline Medical Specialty & & \\
General Practitioner & 58 & 64.4 \\
Gynecologist & 23 & 25.6 \\
Cardiologist & 2 & 2.2 \\
Gynecologist + General Practitioner & 1 & 1.1 \\
Gynecologist + Cardiologist & 1 & 1.1 \\
Other (Pediatrician, Rheumatologist, General Surgeon) & 5 & 5.6 \\
Place of Prescription & & \\
Family health care center (USF) & 54 & 60.0 \\
Basic health care center (UBS) & 4 & 4.4 \\
Outpatient clinic & 1 & 1.1 \\
Hospital & 15 & 16.7 \\
Emergency room & 3 & 3.3 \\
Urgent care center & 2 & 2.2 \\
Hospital + USF/UBS & 2 & 2.2 \\
Private practice & 9 & 10.0 \\
Instructions provided? & & \\
Yes & 58 & 64.4 \\
No & 32 & 35.6 \\
\hline
\end{tabular}

Table 3: Classification of the medications used by nursing mothers. Marília, São Paulo, 2014. The data are presented as absolute frequencies $(n)$ and as percentages.

\begin{tabular}{|c|c|c|c|c|c|}
\hline Variable & & Risk C & gory ${ }^{a}$ & & $\mathbf{p}^{*}$ \\
\hline & $\begin{array}{c}\text { Compatible with } \\
\text { Breastfeeding } \\
\mathrm{n}(\%)\end{array}$ & $\begin{array}{c}\text { Potential Risk } \\
\text { n (\%) }\end{array}$ & $\begin{array}{c}\text { Contraindicated } \\
\mathrm{n}(\%)\end{array}$ & $\begin{array}{c}\text { Not Identified } \\
\mathrm{n}(\%)\end{array}$ & \\
\hline Medical Specialty & & & & & 0.03 \\
\hline $\begin{array}{l}\text { General Practitioner } \\
(\mathrm{ESF})^{\mathrm{b}}\end{array}$ & $33(58.9)$ & $9(90)$ & $10(90.9)$ & $7(53.8)$ & \\
\hline Gynecologist & $19(33.9)$ & $0(0)$ & $0(0)$ & $4(30.8)$ & \\
\hline Other ${ }^{c}$ & $4(7.2)$ & $1(10)$ & $1(9.1)$ & $2(15.4)$ & \\
\hline Location of Care & & & & & 0.001 \\
\hline USF $^{d}$ & $30(53.6)$ & $8(80)$ & $11(100)$ & $5(38.5)$ & \\
\hline Hospital & $15(26.8)$ & $0(0)$ & $0(0)$ & $0(0)$ & \\
\hline Othere & $11(19.6)$ & $2(20)$ & $0(0)$ & $8(61.5)$ & \\
\hline Received Medical Advice? & & & & & 0.68 \\
\hline Yes & $36(64.3)$ & $6(60)$ & $6(54.5)$ & $10(76.9)$ & \\
\hline No & $20(35.7)$ & $4(40)$ & $5(45.5)$ & $3(23.1)$ & \\
\hline
\end{tabular}

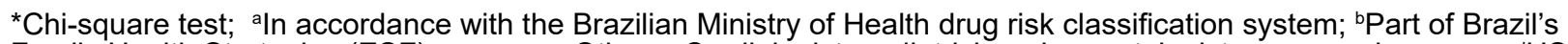
Family Health Strategies (ESF) program; ${ }^{\circ}$ Other = Cardiologist, pediatrician, rheumatologist, or general surgeon; ${ }^{d}$ USF = Brazil's Family Health Care Centers (USFs); ' $O$ Other = Basic health care center (UBS), outpatient clinic, emergency room, or urgent care center. 


\section{DISCUSSION}

The socioeconomic data on the patients' age and level of schooling in the present study resemble those from a study performed in the state of Rio de Janeiro, in which the majority of patients were between 21 and 30 years of age and in which the highest level of schooling of $46 \%$ of the patients was a completed high school education ${ }^{17}$. Variables such as age and schooling have been described as factors associated with early weaning; studies have suggested that the lower the mother's level of schooling, the earlier the weaning tends to take place ${ }^{20}$. In agreement with these findings, another cross-sectional study demonstrated that mothers with less schooling are more likely to introduce foods in their children's diet prematurely ${ }^{21}$. It is also worth mentioning that marital status can also be a determinant of early weaning. Married women seem to be more likely to breastfeed ${ }^{22}$. As detailed in Table 1, the interviews revealed that 90 of the nursing mothers $(55.9 \%)$ used prescription medications. These data are slightly lower than those observed in a study on nursing mothers treated at a public hospital, in which $78 \%$ of the mothers reported using prescribed medication ${ }^{17}$. The current findings were also lower than those in a study on nursing mothers treated at a UBS $(80 \%)^{16}$. In these previous studies, the most commonly prescribed medications were NSAIDs, prescriptions for which ranged from $58 \% 16$ to $61.5 \%{ }^{17}$.

In a cross-sectional study on mothers of infants less than 6 months of age treated in UBSs in the inland cities of São Paulo State, $93 \%$ of the medications the mothers used had been prescribed to them. The most common prescriptions were for vitamins and iron supplements (59\%); antibiotics and antihypertensive drugs totaled only $2 \%$ and $1 \%$, respectively ${ }^{14}$. According to a study carried out in a clinic in the Netherlands, $65.9 \%$ of 451 breastfeeding women used some type of medication, while $40.8 \%$ used vitamin supplements, and $7.1 \%$ oral contraceptives ${ }^{23}$.

In the current study, the most commonly used medications were oral contraceptives, followed by antibiotics and antihypertensive drugs. The high percentage of contraceptive use may be a factor of the predominantly young age of the nursing mothers involved in the study, most of whom were still of childbearing potential. We consider it important to classify contraceptives as combined or non-combined, since the former are contraindicated during lactation: the presence of the estrogen component compromises the breast milk production ${ }^{13}$.

In our study, $7.7 \%$ of the contraceptives prescribed were combined. However, $8.4 \%$ of the women interviewed were unable to specify which contraceptive they used. According to the Brazilian Ministry of Health's risk categories, the antihypertensive drugs and antibiotics prescribed to the women in this study have a potential for risk if used during breastfeeding. Furthermore, 12.2\% of the nursing mothers used contraindicated drugs in this period. This finding differed from a study on mothers treated at the hospital level, where all of the drugs prescribed were in the Ministry of Health's "compatible with breastfeeding" category ${ }^{17}$. In general, studies show that most women use prescription drugs during lactation, but different drug classes are used at different rates, and study results may be influenced by country, the number of nursing mothers considered, and the type of health care service or center where the data is obtained.

As Table 2 details, most of the medications were prescribed to the women in this study by general practitioners. The nursing mothers interviewed in the present study were treated as part of the ESF program, but the results go against the purpose and proposals of Brazil's primary health care system: given the longitudinal nature of the program, the point of this care is not to limit prevention measures only to the prescription of medication ${ }^{24}$; both primary and secondary prevention measures must be prioritized. Though Brazil's USFs do not have gynecologists on staff, the presence of the gynecologists in the data can be explained by the fact that some of the nursing mothers interviewed were treated in a hospital setting.

In the interviews, $64.4 \%$ of the mothers reported having received some kind of medical advice. This rate was similar to those in the literature, in which $76.9 \%$ of the mothers were advised on the use of the drugs by doctors or nurses ${ }^{17,20}$.

Table 3 demonstrates that drug risk classification was positively correlated with the prescribing physician's medical specialty and with the place of care. As mentioned previously, all medication classified as contraindicated was found to have been prescribed as part of primary care (in a local UBS or USF) by general practitioners. This behavior may be a factor of the prescribing physician's medical education, since general practitioners do not routinely have experience with breastfeeding mothers and the types of medications considered safe for them. The presence of gynecologists may have contributed to the lack of contraindicated prescriptions in the other places of care, since OBGYNs are theoretically more qualified to manage these medications during this phase of patients' lives. According to recommendations from the Brazilian Ministry of Health, when pharmacological treatment is required during breastfeeding, the risks to the health of the mother and the child be carefully evaluated so that mothers can be appropriately treated without interrupting breastfeeding ${ }^{19}$.

The statistical analysis showed no positive correlation between medical advice being given and the risk category of the medications prescribed (Table 3 ). However, nine nursing mothers received prescriptions for drugs classified as contraindicated or having the potential for risk if used during breastfeeding. These erroneous prescriptions reflect the need for better training for professionals involved in treating nursing mothers, who require specialized care ${ }^{25}$. 


\section{CONCLUSION}

In terms of sociodemographic data, most of the nursing mothers interviewed in this study were under thirty years of age and had a high-school-level education. The most frequently used drug class was that of contraceptives. Because approximately one fifth of the mothers interviewed reported using combined contraceptives, which are contraindicated by the Brazilian Ministry of Health, and because close to one third of the mothers were prescribed drugs that had a potential for risk if used during breastfeeding, these results reflect the importance of improving the quality of care when it comes to prescribing medications to this population. One limitation of this study is the lack of information on the likely medical issues experienced by these patients, which may have been able to explain the prescription of contraindicated pharmaceuticals.
This study provides evidence that most of the patients interviewed received medical advice regarding the use of medication while breastfeeding, and also that every case in which contraindicated medication was prescribed occurred in a visit with a general practitioner as part of primary care.

These results therefore reflect the need for qualified professionals throughout Brazil's public health care network, since more properly trained professionals will provide more accurate prescriptions and advice regarding the use of medication that is compatible with breastfeeding and will therefore provide better care to both mothers and children.

\section{REFERENCES}

1. Corintio MN. Manual de aleitamento materno. $3^{\mathrm{a}}$ ed. São Paulo: FEBRASGO, 2015.

2. Moura ERBB, Florentino ECL, Bezerra MEB, Machado ALG. Investigação dos fatores sociais que interferem na duração do aleitamento materno exclusivo. Rev Intert. 2015;8(2):94-116. DOI: http://dx.doi.org/10.22280/revintervol8ed2.203

3. Victora CG, Barros AJD, França GVA, Bahl R, Horton S, Krasevec J, et al. Amamentação no século 21: epidemiologia, mecanismos, e efeitos ao longo da vida. Epidemiol Serv Saúde. 2016;1-24.

4. Dias EG, Alves JCS, Santos MRA, Pereira PG. Prevalência do aleitamento materno exclusivo até o sexto mês no município de Mamonas-MG em 2013. Rev Contexto Saúde. 2015;15(29):81-90. DOI: http://dx.doi.org/10.21527/2176-7114.2015.29.81-90

5. Brasil. Ministério da Saúde. Centro Brasileiro de Análise e Planejamento. Pesquisa nacional demográfica e saúde da criança e da mulher PNDS 2006: dimensões do processo reprodutivo e da saúde da criança. [cited 2017 Nov 20] Available from: http://bvsms.saude.gov.br/bvs/publicacoes/pnds_crianca_mulher.pdf.

6. 6. Prado CVC, Fabbro MRC, Ferreira GI. Desmame precoce na perspectiva de puérperas: uma abordagem dialógica. Texto Contexto Enferm. 2016;25(2):e1580015. DOI: http://dx.doi.org/10.1590/0104-07072016001580015

7. Severiano AAO, Dantas DS, Oliveira VLC, Lopes JM, Souza DE, Magalhães AG. Associação entre amamentação, fatores obstétricos e o desenvolvimento infantil de crianças do interior do nordeste brasileiro. J Hum Growth Dev. 2017;27(2):158-65. DOI: http://dx.doi.org/10.7322/jhgd.114483

8. Fonseca-Machado MO, Haas VJ, Stefanello J, Nakano AMS, Gomes-Sponholz F. Aleitamento materno: conhecimento e prática. Rev Esc Enferm USP. 2012;46(4):809-15. DOI: http://dx.doi.org/10.1590/S0080-62342012000400004

9. Silva NM, Waterkemper R, Silva EF, Cordova FP, Bonilha ALL. Conhecimento de puérperas sobre amamentação exclusiva. Rev Bras Enferm. 2014;67(2):290-5. DOI: http://dx.doi.org/10.5935/0034-7167.20140039

10. Silva CA, Davim RMB. Mulher trabalhadora e fatores que interferem na amamentação: revisão integrativa. Rev Rene. 2012;13(5):1208-1217. DOI: http://dx.doi.org/10.15253/rev\%20rene.v13i5.4143

11. Hernandes TA, Fuginami AN, Raimundo EC, Cardoso CP, Higa EFR, Lazarini CA. Significado e dificuldades da amamentação: representação social das mães. Rev Psicol Diversid Saúde. 2017;6(4):247-57. DOI: http://dx.doi.org/10.17267/2317-3394rpds.v6i4.1692

12. Barbosa JAG, Santos FPC, Silva PMC. Fatores associados à baixa adesão ao aleitamento materno exclusivo e ao desmame precoce. Rev Tecer. 2013;6(11):154-65. DOI: http://dx.doi.org/10.15601/1983-7631/rt.v6n11p154-16

13. Brasil. Ministério da Saúde. Secretaria de Atenção à Saúde. Departamento de Atenção Básica. Saúde da criança: aleitamento materno e alimentação complementar. 2ed. Brasília: Ministério da Saúde, 2015.

14. Del Ciampo LA, Ferraz IS, Daneluzzi JC, Ricco RG, Martinelli Junior CE. Aleitamento materno e uso de medicamentos durante a lactação. Rev Paul Pediatr. 2007;25(4):355-7. DOI: http://dx.doi.org/10.1590/S0103-05822007000400010 
15. Queiroz RFC, Santos SLF, Pessoa CV, Borges RN, Barros KBT. Aleitamento materno e uso de medicamentos por puérperas em um município do estado do Ceará. Bol Inform Geum. 2015;6(3):7-14.

16. Mota LS, Chaves EMC, Barbosa RCM, Amaral JF, Farias LM, Almeida, PC. Uso de medicamentos durante a lactação por usuárias de uma unidade básica de saúde. Rev Rene. 2013;14(1):139-47. DOI: http://dx.doi.org/10.15253/rev\%20rene.v14i1.3344

17. Fragoso VMS, Silva ED, Mota JM. Lactantes em tratamento medicamentoso da rede pública de saúde. Rev Bras Promoç Saúde. 2014;27(2):283-90. DOI: http://dx.doi.org/10.5020/18061230.2014.p283

18. World Health Organization (WHO). Collaborating Centre for Drug Statistics Methodology. Guidelines for ATC classification and DDD assignment 2013. Oslo: 2012 [cited 2017 Oct 4]. Available from: https://www.whocc.no/filearchive/publications/1_2013guidelines.pdf.

19. Brasil. Ministério da Saúde. Secretaria de Atenção à Saúde. Departamento de ações pragmáticas e estratégicas. Amamentação e uso de medicamentos e outras substâncias. 2ed. Brasília: Ministério da Saúde, 2014. [cited 2018 Fev 12]. Available from: bvsms.saude.gov.br/bvs/publicacoes/amamentacao_uso_medicamentos_outras_substancias.pdf.

20. Teter MSH, Oselame GB, Neves EB. Amamentação e desmame precoce em lactantes de Curitiba. Espaço Saúde. 2015;16(4):55-63. DOI: http://dx.doi.org/10.22421/1517-7130.2015v16n4p54

21. Pereira RSV, Oliveira MIC, Andrade CLT, Brito AS. Fatores associados ao aleitamento materno exclusivo: o papel do cuidado na atenção básica. Cad Saúde Pública. 2010;26(12):2343-54. DOI: http://dx.doi.org/10.1590/S0102-311X2010001200013

22. Dodt RCM, Ferreira AMV, Nascimento LA, Macêdo AC, Joventino ES, Ximenes LB. Influência de estratégia de educação em saúde mediada por álbum seriado sobre a autoeficácia materna para amamentar. Texto Contexto Enferm. 2013;22(3):610-8. DOI: http://dx.doi.org/10.1590/S0104-07072013000300006

23. E Schirm E, Schwagermann MP, Tobi H, Jong-van den Berg LT. Drug use during breastfeeding. Eur J Clin Nutr. 2004;58(2):386-90. DOI: http://dx.doi.org/10.1038/sj.ejcn.1601799

24. Vitoi NC, Fogal AS, Nascimento CM, Franceschini SCC, Ribeiro AQ. Prevalência e fatores associados ao diabetes em idosos no município de Viçosa, Minas Gerais. Rev Bras Epidemiol. 2015;18(4):953-65. DOI: http://dx.doi.org/10.1590/1980-5497201500040022

25. Maciel JMMP, Ramos AGB. Uso de medicamentos durante a lactação: um fator para a suspenção do aleitamemento materno. Rev Pesq Interdiscipl. 2017;(2):504-13. DOI: http://dx.doi.org/10.24219/rpi.v2i2.274

\section{Resumo}

Introdução: É inquestionável a importância do aleitamento materno. Seus benefícios abrangem o lactente, a nutriz, a família e a sociedade. A Organização Mundial de Saúde preconiza o aleitamento exclusivo até os seis meses de idade, o qual pode ser comprometido por alguns motivos, dentre eles o uso de medicamentos.

Objetivo: Caracterizar os medicamentos utilizados por nutrizes, no que se refere a: categorias de risco; locais e responsáveis pela prescrição médica e orientações recebidas.

Método: estudo transversal, retrospectivo, quantitativo. Os dados foram coletados na Estratégia de Saúde da Família (ESF) com 161 nutrizes nos anos de 2012 e 2013, por meio de questionário estruturado, contendo informações sobre o uso de medicamentos durante a lactação. Os dados foram apresentados em frequências absolutas e relativas, e comparados às variáveis selecionadas no estudo para verificação da existência de associação, utilizando-se o Teste do Qui-quadrado.

Resultados: $55,9 \%$ das entrevistadas referiram uso de medicamentos, predominando os que atuam no Sistema hormonal, seguidos dos de uso sistêmico e cardivascular. O clínico geral foi o que mais prescreveu, seguido do ginecologista, na ESF. $64,4 \%$ das entrevistadas receberam algum tipo de orientação. A análise estatística demonstrou associação positiva entre categoria de risco e as variáveis especialidade médica $(p=0,03)$ e local de atendimento $(p=0,001)$.

Conclusão: A classe de medicamento mais utilizada foi a dos anticoncepcionais. Todo medicamento classificado como contra indicado foi prescrito, na Atenção Primária, pelo clínico geral. Sendo assim, destaca-se a necessidade de profissionais qualificados em toda rede de atenção à saúde.

Palavras-chave: aleitamento materno, prescrições de medicamentos, lactação, saúde materno-infantil, atenção primária à saúde.

${ }^{\oplus}$ The authors (2018), this article is distributed under the terms of the Creative Commons Attribution 4.0 International License (http:// creativecommons.org/licenses/by/4.0/), which permits unrestricted use, distribution, and reproduction in any medium, provided you give appropriate credit to the original author(s) and the source, provide a link to the Creative Commons license, and indicate if changes were made. The Creative Commons Public Domain Dedication waiver (http://creativecommons.org/publicdomain/zero/ $1.0 /$ ) applies to the data made available in this article, unless otherwise stated. 